\title{
The trial of Jeremy Owens
}

The memory lingers on.

\section{Peter Roberts}

The biological Jeremy Owens sat alone at the plaintiff's table. He had been rebuffed by every lawyer he had approached to assist him in this trial; some had laughed in his face. The ridicule only added to his determination to prove that he was the only real, true Jeremy Owens.

The judge entered the courtroom, rolled over to the bench, and made the necessary connections. Everyone was looking at the plaintiff. There was electricity in the air - or perhaps it was just the ozone generated by all the high-powered personages here to observe this high-profile trial.

The biological Jeremy Owens was, as usual, utterly confident. At first he had worried about receiving a fair trial — all the judges were, of course, enhanced. (Who wants justice rendered by mere human brains, so easily deceived, so weak in reason and judgment?) But he realized that the outcome of this trial depended solely on the justice of his claim. He knew he was right; how could he fail?

"I ask the court to consider what it means to be human, to be a person," he began. "It isn't simply a matter of genetics or physiology, defined by legalisms or high-flown philosophy. Rather, personhood consists of all the memories and experiences, thoughts, beliefs and feelings accumulated over a lifetime. I have experienced all the events of my life, whereas the defendant has not. Only I experienced my childhood, my school years, all the physical and emotional changes of growing up. Only I felt the confusion and thrill of my first love, and the trauma of its break-up. Only I suffered the skiing accident that sent me over a cliff and nearly ended my life. And only I have a right to my identity, my personhood. I alone am Jeremy Owens."

The response from the cyborg Jeremy Owens was immediate - and devastating:

"I, too, experienced that dreadful fall, and all the events and emotions of my tumultuous early life, for all the memories and thought patterns accumulated by that former appendage of mine at the plaintiff's table were downloaded and preserved, not to say treasured and learned from, in my extensive and very acute memory. If memory and experience are claimed as

the basis for identity, surely I must be the true possessor of that personhood, which you would claim for yourself? I remember everything you do, and much that you don't, and all of it in greater detail than you. Your memories are incomplete, partial, often faulty or false. Mine are complete, reliable, thorough and true.

"Who is more truly and fully Jeremy Owens? You, with your fuzzy, incomplete, vague recollections? Or me, possessed as I am of sharp, complete and full memories? You are a ghost, a pallid reflection of the body of experiences that forms the real Jeremy Owens. You are just a cast-off remnant, with no more claim on existence, on selfhood, than the thumb I had amputated earlier in my life."

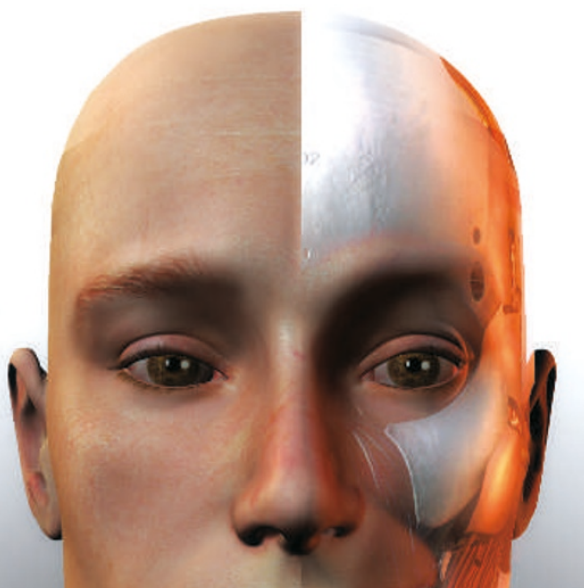

than the new skin, but it is not the snake. Shedding the old skin allows the snake to grow, to become more than it could have been had it retained - and been restricted by - its old skin. The plaintiff is like that discarded snakeskin: a cast off encumbrance, no longer a part of Jeremy Owens. Reinstating him as a part of Jeremy Owens could only diminish and constrain Jeremy Owens, preventing him from attaining his full potential. Surely, the court cannot permit such a miscarriage of justice. For the plaintiff even to claim to be a part of Jeremy Owens, let alone to claim, as he does, that he is Jeremy Owens, is a travesty. Therefore, we are confident that this court will rule in our favour."

Jeremy Owens - the biological Jeremy Owens - sat unmoving, stunned. He could think of nothing more to say.

The judge pronounced a verdict.

"The court finds the arguments of the defendant compelling, those of the plaintiff without merit. Therefore, we must rule in the defendant's favour. Furthermore, as it would be unthinkable to allow a discarded (and possibly defective) component of Jeremy Owens to wander the streets claiming the identity, rights and privileges of the real Jeremy Owens, this court hereby enjoins the plaintiff from pretending to be Jeremy Owens; from using the name of Jeremy Owens in any way when referring to himself; from asserting any ongoing relationship to Jeremy Owens; or from claiming any of the rights or privileges of Jeremy Owens. The court further notes that it entertains grave doubts that the plaintiff is in any sense a person, or that he possesses any of the legal rights of a person. As the court has not yet

"But, I've always been Jeremy Owens; you have not!"

"There has been a continuity and a trajectory from my birth - which produced that part of me now standing before this court as plaintiff — to the present day. The plaintiff is no longer a part of that trajectory, and for the court to recognize him as Jeremy Owens would disrupt the continuity of the life of the true Jeremy Owens, would diminish him, would make him less than he has already become, less than he is capable of being.

"When a snake sheds its skin, the castoff skin has certainly been around longer heard arguments on this issue, however, it would not be proper for it to hand down a ruling on that question."

Dumbfounded, devastated, the now nameless biological remnant of Jeremy Owens sat for a very long while. He was helped out of the building by a kindly officer of the court, who looked like nothing so much as a high-tech wheelchair. Jeremy was grateful for the assistance. Peter Roberts has a BS in mathematics. His poetry and fiction have appeared in a variety of magazines over the past 30 years. See his website at www.geocities. com/peterroberts.geo. 